\title{
CALL FOR PAPERS: \\ GAMING LAW REVIEW
}

EDITOR-IN-CHIEF: STEVE RUDDOCK; BETTINGUSA GROUP

The editorial team of Gaming Law Review, the Official Legal Publication of the International Masters of Gaming Law (IMGL), invites you to submit your manuscript for consideration.

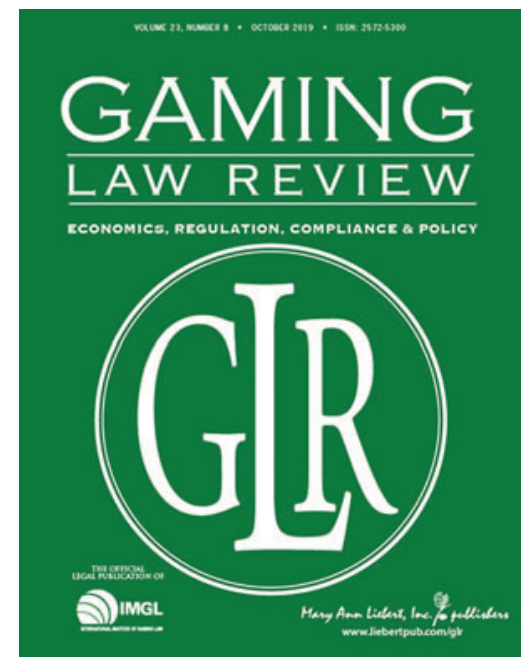

Benefits of publishing with Gaming Law Review include:

- New! Fast and user-friendly electronic submission

- Rapid, high-quality peer review

- Competitive Author Benefits program

- Maximum exposure: accessible in 170 countries worldwide

- Citation tracking and inclusion in bibliographic databases

- Open Access options available

- No submission fees or page charges

Gaming Law Review presents the latest developments in legislation, regulation, and judicial decisions affecting gaming around the world. As the first journal focused on this specialized area of law, it provides exclusive access to historic and current developments that are impacting today's legal cases. With authoritative coverage of the legalities of intellectual property and licensing requirements, past and current litigation, and tax issues, the Journal is cited more often by legal courts than any other gaming law journal.

Submit your paper for peer review online: https://mc.manuscriptcentral.com/glr 